\title{
PENGARUH PEMBELAJARAN FISIKA MENGGUNAKAN DIRECT INSRUCTION (DI) MELALUI PEMODELAN KOREKTIF TERHADAP HASIL BELAJAR FISIKA SISWA KELAS VIII SMPN 2 LABUHAN HAJI TAHUN AJARAN 2013/2014
}

\author{
Zaini $^{1}$, Sutrio ${ }^{2}$, Gunawan² \\ 1) Program Study Pendidikan Fisika \\ 2) Program Study Pendidikan Fisika FKIP \\ Universitas Mataram \\ Mataram, Indonesia
}

\begin{abstract}
This research is research experiments with a purpose to knows the effect of physics learning using direct instruction (DI) throught corrective models toward result of study physics on grade VIII SMPN 2 Labuhan Haji in academic year 2013/2014. This research using the Nonequivalent Multiple Groups Pretest Posttest Design. The technique to obtain the sample using purposive sampling technique. The population in this research is all the Classes VIII SMPN 2 Labuhan Haji. Whereas it's Sample obtained by the student on Grade VIII E as the experiment class and VIII $\mathrm{F}$ as the control class. The data result studying analyzed by $\mathrm{t}$-test two tail using formulas separated variance. From the result of research obtained from materials of pressure and vibration and wave is $t_{\text {count }}=2,646$ and $t_{\text {count }}$ $=6,004$, whereas $t_{\text {table }}=2,012$ on degree of free is 56 with standard significant is $5 \%$. Because $t_{\text {count }}$ on preesure materials and vibration and wave materials biger than $t_{\text {table }}$,so Ho will be rejected and Ha will be accepted which indicate that there are effects of physics learning using direct instruction (DI) throught corrective models toward the result studying physics on grade VIII SMPN 2 Labuhan Haji in academic year 2013/2014.
\end{abstract}

Keywords: direct instruction (DI) throught corrective models, learning outcomes.

\section{Pendahuluan}

Ilmu pengetahuan Alam (IPA) adalah ilmu pengetahuan yang membahas tentang alam berdasarkan hukum-hukum yang sifatnya umum dan dapat berlaku kapanpun dan dimanapun. Pendidikan IPA diharapkan dapat menjadi wahana bagi siswa untuk mempelajari diri sendiri dan alam sekitar, serta prospek pengembangan lebih lanjut dalam menerapkannya di dalam kehidupan sehari-hari. Oleh karena itu proses pembelajaran IPA hendaknya menekankan pada hakikat IPA itu sendiri. Hakikat IPA adalah ilmu pengetahuan yang mempelajari gejala-gejala melalui serangkaian proses yang dikenal dengan proses ilmiah yang dibangun atas dasar sikap ilmiah dan hasilnya terwujud sebagai produk ilmiah yang tersusun atas tiga komponen terpenting berupa konsep, prinsip, dan teori yang berlaku secara universal [1]. Fisika merupakan bagian dari IPA atau sains, maka hakikat fisika sama dengann hakikat IPA atau sains yakni fisika sebagai proses, fisika sebagai sikap, dan fisika sebagai produk.

Dalam penyampaian materi di dalam kelas, hakikat fisika itu sering diabaikan, siswa dituntut untuk menghafal rumus-rumus dan mencatat tanpa memberikan pemahaman terlebih dahulu. Sehingga pelajaran fisika merupakan pelajaran yang selalu dianggap sulit, tidak menarik, dan menakutkan bagi siswa. Sebagian besar pembelajaran fisika dilakukan dengan model pengajaran konvensional yang membuat siswa tidak mendapatkan kesempatan untuk aktif dalam proses belajar mengajar.

Berdasarkan observasi terhadap proses belajar mengajar yang dilakukan di kelas VIII pada populasi penelitian ditemukan fakta-fakta bahwa metode pembelajaran yang digunakan adalah metode ceramah, hanya beberapa kali saja menggunakan metode eksperimen dan demonstrasi, siswa kurang termotivasi dalam belajar fisika karena mereka tidak mau belajar sebelumnya dari rumah, serta siswa lebih senang belajar di laboratorium dari pada belajar di kelas. Selain itu juga diperoleh data bahwa nilai siswa masih di bawah kriteria ketuntasan minimum (KKM) yakni 72.

Salah satu cara untuk mendapatkan keberhasilan dalam pembelajaran adalah mengajarkan pengetahuan deklaratif dan prosedural yang terstruktur dengan baik. Model pembelajaran yang berkaitan dengan pengetahuan deklaratif dan pengetahuan prosedural adalah model pembelajaran langsung (Direci Instruction). Adapun Metode yang dapat membantu peserta didik untuk mencari tujuan tersebut adalah variasi antara metode ceramah dan demonstrasi yang dikemas dalam model pengajaran langsung (direct 
instruction) [2]. Model Direct Instruction menuntut dan membantu siswa dalam meningkatkan hasil belajar siswa.

Model pengajaran langsung adalah salah satu pendekatan mengajar yang dirancang khusus untuk menunjang proses belajar siswa yang berkaitan dengan pengetahuan deklaratif dan pengetahuan prosedural yang terstruktur dengan baik yang dapat diajarkan dengan pola kegiatan bertahap, selangkah demi selangkah [1]. Model pembelajaran ini sering diterapkan di dalam kelas sehingga, siswa tidak jauh mengalami perubahan terhadap kebiasaan pembelajaran. Namun agar siswa lebih memahami konsep secara mendalam yang tidak terlepas dari kehidupan sehari-hari, maka peneliti menerapkan pemodelan yang sifatnya korektif terhadap apa yang telah dilakukan oleh para siswa. Pengaturan waktu dan jenis umpan balik yang diberikan guru merupakan faktor penentu keberhasilan suatu pelatihan. Terutama pada awal pembelajaran umpan balik perlu diberikan segera mungkin, positif dan korektif [3]. Hal inilah yang menyebabkan siswa dapat membentuk keaktifannya dalam belajar, sehingga dapat meningkatkan hasil belajar.

\section{Metode Penelitian}

Penelitian ini dilaksanakan pada kelas VIII SMPN 2 Labuhan Haji tahun ajaran 2013/2014. Jenis penelitian ini adalah penelitian eksperimen yaitu metode penelitian yang digunakan untuk mengetahui pengaruh dari suatu tindakan atau perlakuan tertentu yang sengaja dilakukan terhadap suatu kondisi tertentu [4]. Penelitian ini dilaksanakan pada semester II dari tanggal 17 Maret sampai tanggal 21 April 2014. Desain penelitian menggunakan Nonequivalent Control Group Design. Adapun teknik pengambilan sampel yang digunakan adalah purposive sampling, yaitu teknik pengambilan sampel dengan alasan-alasan tertentu. Sampel penelitian ini adalah 58 siswa yang terbagi dalam dua kelas yaitu, kelas VIII E sebagai kelas eksperimen dan VIII F sebagai kelas kontrol.

Prosedur dan langkah-langkah yang digunakan dalam melaksanakan penelitian ini mengikuti langkahlangkah pada pembelajaran langsung melalui pemodelan korektif. Permasalahan yang dikaji dalam penelitian ini adalah hasil belajar fisika siswa. Agar dapat mengatasi permasalahan tersebut dilakukan tindakan berupa penggunaan direct instruction (DI) melalui pemodelan korektif pada materi tekanan, getaran dan gelombang untuk meningkatkan hasil belajar fisika siswa.

Pada penelitian ini ada tiga variabel yang menjadi fokus penelitian yaitu variabel bebas, variabel kontrol, dan variabel terikat. Variabel bebas pada penelitian ini adalah model pembelajaran, variabel terikat adalah hasil belajar fisika siswa, dan variabel kontrol instrumen penelitian, evaluasi. Teknik pengumpulan data pada penelitian ini adalah tes hasil belajar. Data hasil belajar merupakan data tes awal sebelum diberikan perlakuan dan tes akhir yang dilakukan setelah perlakuan. Data tes awal (pretest) dan tes akhir (posttest) diperoleh dengan menggunakan instrumen yang telah diujicobakan kepada 50 orang siswa kelas IX di SMPN 2 Labuhan Haji tahun ajaran 2013/2014 yang diukur dengan uji validitas, reliabilitas, tingkat kesukaran, dan daya eda soal. Berdasarkan hasil uji coba 60 butir soal materi tekanan, getaran dan gelombang diperoleh 40 soal yang baik digunakan untuk pretest dan posttest. Analisis valiiditas instrumen menggunakan rumus product moment untuk menguji validitas soal dan KR-20 untuk uji reliabilitas soal. Analisis data tes akhir menggunakan uji-t dua pihak.

\section{Hasil dan PEMbahasan}

Hasil penelitian berupa deskripsi hasil tes awal dan tes akhir dengan menggunakan uji homogenitas, uji normalitas dan uji hipotesis (uji-t dua pihak). Adapun hasil rekapitulasi nilai tes awal pada kelas eksperimen dan kelas kontrol materi tekanan, getaran dan gelombang dapat dilihat pada tabel berikut.

Tabel 1. Rekapitulasi Nilai Tes Awal Pada Kelas Eksperimen dan Kelas Kontrol Materi Tekanan

\begin{tabular}{lcc}
\hline \multirow{2}{*}{ Komponen } & \multicolumn{2}{c}{$\begin{array}{c}\text { Kemampuan Awal } \\
\text { (Pretest) }\end{array}$} \\
\cline { 2 - 3 } & Kelas & Kelas \\
Eksperimen & Kontrol \\
\hline Jumlah siswa & 29 & 29 \\
Nilai tertinggi & 50 & 45 \\
Nilai terendah & 10 & 5 \\
Rata-rata & 29,14 & 25,00 \\
Standar & 10,44 & 8,02 \\
Deviasi(SD) & \multicolumn{2}{c}{ Homogen } \\
Uji & \multicolumn{2}{c}{} \\
Homogenitas & \multicolumn{2}{c}{ Normal } \\
Uji Normalitas & Normal \\
Uji Hipotesis & $\mathbf{t}_{\text {hitung }}<\mathbf{t}_{\text {tabel }}=\mathrm{H}_{0}$ diterima \\
\hline
\end{tabular}

Tabel 2. Rekapitulasi Nilai Tes Awal Pada Kelas Eksperimen dan Kelas Kontrol Materi Getaran dan Gelombang

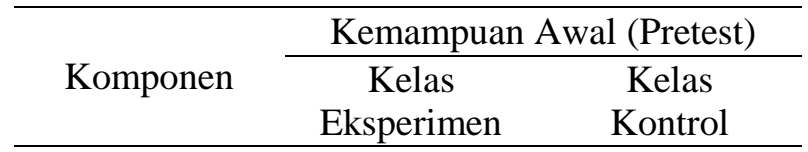




\begin{tabular}{|c|c|c|}
\hline Jumlah siswa & 29 & 29 \\
\hline Nilai tertinggi & 65 & 50 \\
\hline Nilai terendah & 15 & 10 \\
\hline Rata-rata & 36,21 & 29,31 \\
\hline Standar & 14,80 & 11,47 \\
\hline Deviasi(SD) & & \\
\hline Uji & \multirow{2}{*}{\multicolumn{2}{|c|}{ Homogen }} \\
\hline Homogenitas & & \\
\hline Uji Normalitas & Normal & Normal \\
\hline Uji Hipotesis & \multicolumn{2}{|c|}{$\mathbf{t}_{\text {hitung }}<\mathbf{t}_{\text {tabel }}=\mathrm{H}_{0}$ diterima } \\
\hline
\end{tabular}

Berdasarkan tabel hasil tes awal materi tekanan di atas menunjukkan data homogen dan terdidstribusi normal. Untuk uji hipotesisnya dianalis dengan menggunakan uji-t dua pihak dengan Ho diterima, dimana t_hitung $\leq \mathrm{t} \_t a b e l$, yaitu 2,195 < 11,07. Sehingga dapat disimpulkan bahwa tidak terdapat perbedaan hasil belajar antara kelompok kelas eksperimen dan kelass kontrol, yang berarrti bahwa kemampuan kedua kelas adalah sama. Sedangkan, berdasarkan tabel hasil tes awal materi getaran dan gelombang di atas menunjukkan data homogen dan terdidstribusi normal. Untuk uji hipotesisnya dianalis dengan menggunakan uji-t dua pihak dengan Ho diterima, dimana $t$ hitung $\leq \mathrm{t}$ _tabel, yaitu $8,68<11,07$. Sehingga dapat disimpulkan bahwa tidak terdapat perbedaan hasil belajar antara kelompok kelas eksperimen dan kelass kontrol, yang berarti bahwa kemampuan kedua kelas adalah sama.

Berkenaan dengan hasil tes akhir, diperoleh hasil belajar pada materi tekanan kelompok eksperimen memiliki rata-rata kelas sebesar 81,55 sedangkan kelompok kontrol memiliki rata-rata kelas sebesar 77,07 . Untuk materi getaran dan gelombang kelompok eksperimen memiliki rata-rata kelas sebesar 83,97 sedangkan kelompok kontrol memiliki rata-rata kelas sebesar 72,93. Hal ini menunjukkan bahwa kelompok siswa yang mengikuti pembelajaran dengan pembelajaran langsung melalui pemodelan korektif (kelas eksperimen) lebih tinggi dari pada kelompok siswa yang mengikuti pembelajaran dengan pembelajaran konvensional (kelas kontrol).

Berdasarkan uji statistik (uji-t) pada hasil tes akhir pada materi tekanan, didapatkan harga t_hitung $=2,646$ dan harga ini lebih besar dari harga t_tabel=2,012, sedangkan pada materi getaran dan gelombang diperoleh harga t_hitung=6,004 dan harga ini lebih besar dari harga t_tabel=2,012. Sehingga dapat disimpulkan bahwa H_o ditolak dan H_a diterima. Hal ini mengandung pengertian bahwa pembelajaran fisika menggunakan direct instruction (DI) melalui pemodelan korektif berpengaruh terhadap hasil belajar fisika siswa kelas VIII SMPN 2 Labuhan Haji tahun ajaran 2013/2014.

Untuk mengetahui signifikansi peningkatan hasil belajar dan penguasaan konsep siswa pada materi getaran dan gelombang, maka dilakukan perhitungan uji normal gain (N-Gain). Adapun data hasil perhitungan NGain dapat dilihat pada tabel berikut.

Model pembelajaran Direct Instruction melalui pemodelan korektif merupakan suatu teknik menerapkan model pembelajaran langsung dengan menampilkan tingkah laku berupa demonstrasi atau percobaan untuk meningkatkan pemahaman siswa terhadap suatu materi setelah melakukan suatu percobaan. Dalam kegiatan penelitian ini, siswa diberikan LKS untuk melakukan suatu percobaan yang sebelumnya telah didemonstrasikan. Pada kelas eksperimen, setelah siswa melakukan percobaan peneliti kembali memberikan pemodelan yang sifatnya korektif, sehingga dapat membantu siswa dalam meningkatkan pemahaman mereka mengenai materi yang diajarkan dan memberikan pengaruh yang positif terhadap hasil belajar fisika siswa yakni terlihat dari peningkatan hasil belajar fisika siswa.

Hasil penelitian ini diperkuat oleh beberapa teori yang menyatakan bahwa pembelajaran langsung menekankan belajar sebagai perubahan prilaku [5]. Jika behaviorisme menekankan belajar sebagai proses stimulus-respons bersifat mekanis, maka teori belajar sosial beraksentuasi pada perubahan prilaku bersifat organis melalui peniruan. Teori lain juga menyatakan bahwa untuk belajar melalui model, dimana seorang meniru prilaku orang lain yang disebut belajar, yaitu: belajar atas kegagalan dan keberhasilan orang, dan pada akhirnya seseorang meniru dengan dirinya akan matang karena telah melihat pengalaman-pengalaman yang dicoba orang lain [6]. Adapun penelitian sebelumnya yang mendukung penelitian ini menunjukkan bahwa dengan menerapkan model Direct Instruction maka pengetahuan dan keterampilan dapat diterima dan terserap dengan baik oleh seluruh siswa [7]. Sedangkan hasil penelitan lain juga menyatakan bahwa dengan menerapkan pembelajaran langsung disimpulkan terdapat perbedaan yang signifikan antara rata-rata skor tes akhir kelas eksperimen dengan kelas kontrol pada siswa kelas VIII SMP Islamiyah Ciputat [8].

Dari hasil penelitian ini dapat dikatakan bahwa model pembelajaran langsung (Direct Instruction) melalui pemodelan korektif dapat memberikan pengaruh positif terhadap hasil belajar fisika siswa. Jadi dalam kegiatan belajar mengajar, guru dapat menerapkan model Direct Instruction melalui pemodelan korektif 
untuk dijadikan sebagai salah satu alternatif model pembelajaran yang dapat diterapkan, karena sebagai seorang guru harus mampu memilih dan menggunakan model pembelajaran yang tepat untuk diterapkan pada siswa dan keadaan di lingkungan sekolah.

\section{PENUTUP}

Berdasarkan hasil penelitian dan pembahasan maka dapat disimpulkan bahwa pembelajaran fisika menggunakan direct instruction (DI) melalui pemodelan korektif berpengaruh terhadap hasil belajar fisika siswa SMPN 2 Labuhan Haji tahun ajaran 2013/2014. Hal ini dibuktikan oleh hasil belajar fisika siswa yang diajarkan dengan model direct instruction melalui pemodelan korektif lebih tinggi dari pada hasil belajar siswa yang diajarkan dengan pembelajaran konvensional.

\section{REFERENSI}

[1] Trianto. 2007. Model-model Pembelajajaran Inovatif Berorientasi Konstruktivistik. Jakarta: Prestasi Pustaka.

[2] Jufri, W. 2013. Belajar dan Pembelajaran Sains. Bandung: Pustaka Reka Cipta.
[3] Isna. Bq. 2005. Pengaruh Pembelajaran Fisika Menggunakan Model Direct Instruction Melalui Pemodelan Korektif Terhadap Daya Serap Siswa. Skripsi Jurusan Pendidikan Fisika FPMIPA Universitas Mataram. Tidak diterbitkan.

[4] Sanjaya, H. W. 2013. Penelitian Pendidikan.Jakarta: Kencana Prenada Media Group.

[5] Suprijono, A. 2010. Cooperative Learning. Yogyakarta: Pustaka Pelajar.

[6] Yamin, M. 2012. Desain Baru Pembelajaran Konstruktivistik. Jambi: Referensi.

[7] Wawan, S., Fitrajaya, E., Mardiyanti, T. 2010. Penerapan Model Pengajaran Langsung (Direct Instruction) untuk Meningkatkan Pemahaman Belajar Siswa dalam Pembelajaran Rekayasa Perangkat Lunak (RPL). Jurnal Pendidikan Teknologi Informasi dan Komunikasi FPMIPA UPI. Tidak diterbitkan.

[8] Sofiyah. 2010. Pengaruh Model Pengajaran Langsung (Direct Instruction) Terhadap Hasil Belajar Fisika Siswa. Skripsi Jurusan Pendidikan Ilmu Pengetahuan Alam Universitas Islam Negeri Syarif Hidayatullah: Tidak diterbitkan. 